\title{
Time to Terminate Vacuum-assisted Closure and Convert to Primary Abdominal Closure in Intra-abdominal Sepsis
}

\author{
İntra-abdominal Sepsiste Vakum-yardımlı Kapama Sonlandırma ve Primer Abdominal \\ Kapamaya Dönüștürme Zamanı
}

(D) Murat Çikot, (D) Eyüp Gemici, (D) Nuri Alper Sahbaz

İstanbul Bakırköy Dr. Sadi Konuk Training and Research Hospital, Clinic of General Surgery, İstanbul, Turkey

\begin{abstract}
Introduction: There is no widely accepted surgical technique in intra-abdominal sepsis and there is also limited data on available surgical techniques and their outcomes. There is no significant difference between these techniques. The aim of the laparotomy, which is performed to control the source of sepsis, is to reduce mortality. This retrospective study was performed to investigate daily analysis of the effects of vacuum-assisted closure (VAC) on intra-abdominal inflammation, sepsis and mortality.

Methods: The study included 159 patients who underwent VAC technique between January 2010 and April 2017. Statistical analysis of the effects of VAC technique was performed on a daily basis using APACHE IV score, Mannheim peritonitis index (MPI) and Sepsis-Related Organ Failure Assessment (SOFA) score.

Results: VAC changes had a significant effect on APACHE IV score, MPI and SOFA score $(p=0.0001)$. Although there was no significant difference in the SOFA scores between the $1^{\text {st }}$ and $2^{\text {nd }}$ changes or between the $3^{\text {rd }}$ and $4^{\text {th }}$ changes, there was a decrease in values over time.

Conclusion: In the treatment of abdominal contamination with sepsis, VAC use had a positive effect on contamination by decreasing the predicted mortality rate on a daily basis. Although it had a positive effect on sepsis, the effect of VAC on sepsis alone was not significant.
\end{abstract}

Keywords: Vacuum-assisted closure, intra-abdominal sepsis, controlled exploration, treatment öz

Amaç: Intra-abdominal sepsis durumunda yaygın kabul gören cerrahi teknik yoktur, mevcut teknikler ve sonuçları hakkında da sınırlı veri bulunmaktadır. Bu teknikler arasında anlamlı farklılık yoktur. Sepsis kaynağının kontrolü için yapılan laparotomilerde amaç mortaliteyi azaltmaktır. Bu retrospektif çalışma; vakum-yardımlı kapama (VAK) uygulamasının günler bazında intraabdominal enflamasyona, sepsis tablosuna ve mortaliteye etkisini araștırmak amacıyla planlandı.

Yöntemler: Çalıșmaya 2010 Ocak-2017 Nisan tarihleri arasında VAK uygulaması yapılan 159 hasta dahil edildi. APACHE IV skoru, Mainhaim peritonit indeksi (MPi) ve Sepsisle Illgili Organ Yetmezliği Değerlendirmesi (SOFA) skoru kullanılarak VAK uygulamasının günler bazında etkilerinin istatistiksel analizi yapıldı.

Bulgular: VAK değişimlerinin APACHE IV skoru, MPI, SOFA değerleri üzerinde anlamlı etkiye sahipdi ( $p=0,0001$ ). SOFA skorlarında 1. değișim ile 2. değișim arasında, 3. değișim ile 4. değişim arasında anlamlı farklılık olmamasına rağmen değerlerde zamana göre bir azalma vardı.

Sonuç: Sepsis tablosuyla kombine abdominal kontaminasyon tedavisinde, VAK uygulamasının günler bazında, beklenen mortalite oranını azaltarak kontaminasyon üzerine olumlu etkiye sahip olduğu tespit edilmiștir. Sepsis tablosuna olumlu etkisi olmasına rağmen, VAK'nin sadece sepsise üzerine etkisi anlamlı değildi.

Anahtar Kelimeler: Vakum-yardımlı kapama, intra-abdominal sepsis, kontrollü eksplorasyon, tedavi

\section{Introduction}

The main objective of damage control surgery is to manage high intraabdominal pressure and abdominal contamination, as initially identified during trauma surgery in cases of intra-abdominal sepsis (1-3). In these cases, there are no widely accepted surgical techniques. There is limited data on surgical techniques and outcomes in cases of intra-abdominal sepsis, which can be considered a disaster chain (4), and no significant difference was found between different surgical techniques (5). In the 1990s, Wittmann reported that repeated laparotomies within 48-72 hours in abdominal sepsis reduced the mortality rate from $43 \%$ to $28 \%$ compared to that the use of primary abdominal closure (PAC) based on 
the APACHE II score (6). The usefulness of the vacuum-assisted closure (VAC) system, described in the late 1990s, has been supported by studies reporting that the system decreased the pressure caused by intraabdominal contamination in sepsis; moreover, that the system allowed determination of postoperative edema and facilitated patient transport. VAC system also allows patients to remain mobile and enables improved nursing services $(7,8)$. Nonetheless, there is insufficient data to allow a complete evaluation of the efficacy of VAC in cases of sepsis caused by intra-abdominal contamination, as well as the effect on the predicted survival rate.

In this retrospective study of a large patient cohort, the early effects of the VAC system on predicted survival rates, peritonitis, and the severity of sepsis according to the APACHE IV score (it was useful for quality assessment and predicting mortality in intensive care units), the Mannheim peritonitis index, and the Sequential Organ Failure Assessment (SOFA) score were evaluated in cases of intra-abdominal sepsis.

\section{Methods}

The records of 159 patients, who underwent emergency surgery between January 2010 and April 2017 for acute abdominal conditions, with subsequent use of VAC due to intra-abdominal contamination and high pressure, were reviewed. The study protocol was approved by the Ethics Committee of the İstanbul Bakırköy Dr. Sadi Konuk Training and Research Hospital (decision no: 2019/245). Informed consent was obtained from the patients. VAC is an aspiration system that is placed in the abdominal cavity after exploration under general anesthesia. It is used for control of intraabdominal pressure and sepsis source. For this purpose, VAC was performed in patients with anastomotic leak. Daily changes in APACHE IV, Mannheim peritonitis index (MPI) and SOFA scores were not investigated in patients with PAC. Patients who underwent VAC due to trauma, necrotizing fasciitis or Fournier gangrene and patients who were explored before 72 hours were excluded from this study.

Data on the $1^{\text {st }}, 2^{\text {nd }}, 3^{\text {rd }}$ and $4^{\text {th }}$ VAC application days were evaluated to assess early efficacy. VAC system applied following source control was changed within 72 hours after evaluation of peritoneal contamination, intestinal edema, hemodynamic instability, and intra-abdominal compartment criteria.

Table 1. Demographic data of the study

\begin{tabular}{|l|l|l|}
\hline & $\mathbf{n}$ & Age \\
\hline Large bowel perforation & 23 & $53(20-84)$ \\
\hline Small bowel perforation & 20 & $53(22-72)$ \\
\hline Ischemia/Infarct & 18 & $60(46-77)$ \\
\hline Anastomotic failure & 47 & $60(20-83)$ \\
\hline Abscess & 10 & $56(36-79)$ \\
\hline Necrotizing pancreatitis & 4 & $43(27-62)$ \\
\hline Gastric Perforation & 17 & $54(19-73)$ \\
\hline Biliary complication & 20 & $61(22-77)$ \\
\hline TOTAL & 159 & $55(19-84)$ \\
\hline
\end{tabular}

VAC: vacuum-assisted closure
On the preoperative day and postoperative $3^{\text {rd }}, 6^{\text {th }}$ and $9^{\text {th }}$ days, patients with available data on history, age, gender, American Society of Anesthesiologists score, temperature, heart rate, respiratory rate, $\mathrm{PaO}_{2} /$ $\mathrm{FiO}_{2} \mathrm{mmHg}, \mathrm{PO}_{2}, \mathrm{PCO}_{2}$, use of mechanical ventilation, arterial $\mathrm{pH}, \mathrm{Na}+$, platelet count, bilirubin, albumin, hematocrit, leukocyte count, mean arterial pressure, Glasgow Coma scale score, creatinine, urine output and preoperative intra-abdominal contamination findings were included in this study. The effects of VAC application on the predicted mortality rate, peritonitis findings and sepsis were evaluated on a daily basis according to the APACHE IV, MPI, and SOFA scores.

\section{Statistical Analysis}

Qualitative variables were expressed as frequencies and percentages, and quantitative variables were expressed as mean and standard deviation. Repeated measures analysis of variance (ANOVA) was used to detect temporal changes in the APACHE IV, MPI and SOFA scores. A p-value of $<0.05$ was considered statistically significant. Statistical analyses were performed using Number Cruncher Statistical System 11 software.

\section{Results}

The mean age of the patients was 55 years (range: 19-84). The study included 61 women and 98 men. VAC was used for large bowel perforation in 23 patients, small bowel perforation in 20, mesenteric ischemia in 18, anastomotic failure in 47 , necrotizing pancreatitis in four, gastric perforation in 17 and biliary complications in 20 patients (Table 1).

VAC changes had a significant effect on the APACHE IV score $(p=0.0001)$, accounting for $89.1 \%$ of the variations in the APACHE IV measurements. The Bonferroni test revealed significant differences between the $1^{\text {st }}$ and $2^{\text {nd }}$ changes $(p=0.0001)$, between the $1^{\text {st }}$ and $3^{\text {rd }}$ changes $(p=0.0001)$, between the $1^{\text {st }}$ and $4^{\text {th }}$ changes $(p=0.0001)$, between the $2^{\text {nd }}$ and $3^{\text {rd }}$ changes $(p=0.0001)$, between the $2^{\text {nd }}$ and $4^{\text {th }}$ changes $(p=0.0001)$, and between the $3^{\text {rd }}$ and $4^{\text {th }}$ changes $(p=0.0001)$. When the mean values of the measurements were examined, VAC change was observed to decrease APACHE IV scores (Table 2).

VAC changes had a significant effect on MPI $(p=0.0001)$, accounting for $92.2 \%$ of the changes in the MPI. There were significant differences between the $1^{\text {st }}$ and $2^{\text {nd }}$ changes $(p=0.0001)$, between the $1^{\text {st }}$ and $3^{\text {rd }}$ changes $(p=0.0001)$, between the $1^{\text {st }}$ and $4^{\text {th }}$ changes $(p=0.0001)$, 
between the $2^{\text {nd }}$ and $3^{\text {rd }}$ changes $(p=0.0001)$, between the $2^{\text {nd }}$ and $4^{\text {th }}$ changes $(p=0.0001)$, and between the $3^{\text {rd }}$ and $4^{\text {th }}$ changes $(p=0.0001)$.
When the mean values of the measurements were examined, VAC changes were observed to decrease MPI (Table 3).

\section{Table 2. Assessment of the APACHE 4 score according to time}

\begin{tabular}{|c|c|c|c|c|}
\hline APACHE 4 & Mean \pm SD & Median (maximum-minimum) & $\mathbf{p}^{*}$ & Eta-squared \\
\hline Day 1 & $70.97 \pm 13.93$ & $67.00(99.00-42.00)$ & 0.0001 & 0.891 \\
\hline Day 2 & $67.49 \pm 14.81$ & $64.00(98.00-40.00)$ & - & - \\
\hline Day 3 & $60.08 \pm 14.67$ & $55.00(92.00-39.00)$ & - & - \\
\hline Day 4 & $53.09 \pm 14.26$ & $47.00(90.00-38.00)$ & - & - \\
\hline \multicolumn{5}{|c|}{ Bonferroni post-hoc test } \\
\hline & $\mathrm{p}^{* *}$ & - & - & - \\
\hline Day 1/Day 2 & 0.0001 & - & - & - \\
\hline Day 1/Day 3 & 0.0001 & - & - & - \\
\hline Day 1/Day 4 & 0.0001 & - & - & - \\
\hline Day 2/Day 3 & 0.0001 & - & - & - \\
\hline Day 2/Day 4 & 0.0001 & - & - & - \\
\hline Day 3/Day 4 & 0.0001 & - & - & - \\
\hline \multicolumn{5}{|c|}{ *ANOVA Test, **Bonferroni Test } \\
\hline
\end{tabular}

\section{Table 3. Assessment of Mannheim peritonitis indices according to time}

\begin{tabular}{|c|c|c|c|c|}
\hline Mannheim & Mean \pm SD & Median (maximum-minimum) & $p^{*}$ & Eta-Squared \\
\hline Day 1 & $37.87 \pm 5.57$ & $38.00(53.00-27.00)$ & 0.0001 & 0.922 \\
\hline Day 2 & $32.78 \pm 6.46$ & $33.00(48.00-16.00)$ & - & - \\
\hline Day 3 & $25.69 \pm 6.26$ & $25.00(39.00-10.00)$ & - & - \\
\hline Day 4 & $18.01 \pm 5.80$ & $17.00(32.00-3.00)$ & - & - \\
\hline \multicolumn{5}{|c|}{ Bonferroni post-hoc test } \\
\hline & $p^{* *}$ & - & - & - \\
\hline Day $1 /$ Day 2 & 0.0001 & - & - & - \\
\hline Day $1 /$ Day 3 & 0.0001 & - & - & - \\
\hline Day 1/ Day 4 & 0.0001 & - & - & - \\
\hline Day 2/ Day 3 & 0.0001 & - & - & - \\
\hline Day 2/ Day 4 & 0.0001 & - & - & - \\
\hline Day 3/ Day 4 & 0.0001 & - & - & - \\
\hline \multicolumn{5}{|c|}{ *ANOVA Test, ${ }^{* *}$ Bonferroni Test } \\
\hline
\end{tabular}

Table 4. Assessment of SOFA values according to time

\begin{tabular}{|l|l|l|l|l|}
\hline SOFA & Mean \pm SD & Median (maximum-minimum) & p* $^{*}$ & Eta-Squared \\
\hline Day 1 & $1.86 \pm 0.79$ & $2.00(3.00-1.00)$ & 0.0001 & -240 \\
\hline Day 2 & $1.82 \pm 0.87$ & $2.00(3.00-0.00)$ & - & - \\
\hline Day 3 & $1.40 \pm 1.09$ & $1.00(3.00-0.00)$ & - & - \\
\hline Day 4 & $1.26 \pm 1.45$ & $0.00(4.00-0.00)$ & - & - \\
\hline Bonferroni Post-Hoc test & & - & - & - \\
\hline & $p^{* *}$ & - & - & - \\
\hline Day 1/Day 2 & 1.00 & - & - & - \\
\hline Day 1/Day 3 & 0.0001 & - & - & - \\
\hline Day 1/Day 4 & 0.0001 & - & - & - \\
\hline Day 2/Day 3 & 0.0001 & - & - & - \\
\hline Day 2/Day 4 & 0.0001 & - & - & - \\
\hline $\begin{array}{l}\text { Day 3/Day 4 } \\
\text { *ANOVA test, **Bonferroni Test }\end{array}$ & 0.079 & & \\
\hline SD: standard deviation & & & \\
\hline
\end{tabular}


VAC change had a significant effect on SOFA scores $(p=0.0001)$, accounting for $24 \%$ of the changes in SOFA measurements. Significant differences were observed between the $1^{\text {st }}$ and $3^{\text {rd }}$ changes $(p=0.0001)$, between the $1^{\text {st }}$ and $4^{\text {th }}$ changes $(p=0.0001)$, between the $2^{\text {nd }}$ and $3^{\text {rd }}$ changes $(p=0.0001)$, and between the $2^{\text {nd }}$ and $4^{\text {th }}$ changes $(p=0.0001)$. No significant difference was observed between the $1^{\text {st }}$ and $2^{\text {nd }}$ changes $(p=1.00)$ or between the $3^{\text {rd }}$ and $4^{\text {th }}$ changes $(p=0.079)$. Although there was no significant difference between the $1^{\text {st }}$ and $2^{\text {nd }}$ changes, or between the $3^{\text {rd }}$ and $4^{\text {th }}$ changes, a temporal decrease was observed when the mean measurement values were examined (Table 4).

\section{Discussion}

Intra-abdominal sepsis may gradually progress to severe sepsis, septic shock and even organ failure in some cases (9). The concept of repeat laparotomy for the treatment of severe peritonitis has long been discussed. Although not routinely recommended for intra-abdominal sepsis in the current guidelines, the open abdominal approach is still accepted as an important strategy (10). It has been reported that this approach can provide better source control and enable anastomosis under better conditions, while also preventing intra-abdominal compartment syndrome (11-13).

Although studies have reported that negative pressure therapy, which is commonly used in cases of increased intra-abdominal pressure and sepsis, is effective in the abdominal wall formation, few studies have evaluated the effects of this method on intra-abdominal peritonitis and sepsis. Negative pressure therapy, however, has been reported as a promising method, particularly in source control (14).

The findings showed that VAC had a positive effect on predicted survival rates, based on the APACHE IV score, which is used to determine the predicted survival rate of patients in the intensive care unit. The decrease in the APACHE IV score was found to be statistically significant ( $p=0.0001$ ), and a statistically significant difference was also found between the APACHE IV score on the day VAC was applied and on the daily scores $(p=0.0001)$. Every day of VAC application, the APACHE IV score was observed to decrease, and thus the predicted mortality rate decreased.

This positive effect of VAC on APACHE IV scores was detected in MPI $(p=0.0001)$. In particular, VAC application, which had a positive effect on contamination and intestinal edema, had a positive effect on MPI $(p=0.0001)$. It is apparent that use of the VAC system for an open abdominal protocol may have positive effects on peritoneal contamination and intestinal edema. Our results showed that VAC application provided good source control.

It was noted that changes in the SOFA score between VAC application days were not statistically significant, although VAC had a positive effect on the SOFA score. This finding suggests that VAC application has a positive effect on the local effects of peritonitis, although the expected positive systemic effects were not observed at the expected level. VAC therapy increased peritoneal fluid concentrations of interleukin (IL)-6, IL-17, IL-5, and human growth factor more than PAC, therefore increased peritoneal cytokines were found to lead to progression of abdominal sepsis in a study (15). The application of an abdominal management method in cases of abdominal sepsis has several advantages, including the diagnosis and treatment of residual infections, infection source control, removal of infected and cytokine-loaded peritoneal fluids, and prevention of abdominal compartment syndrome, and can serve as a temporizing measure pending permanent intervention until the patient is appropriately resuscitated and hemodynamically stabilized (16). However, our findings suggest that VAC application does not reduce sepsis control. VAC should be terminated with PAC application in patients who achieve source control and normalized intra-abdominal pressure (i.e., as early as possible).

This retrospective study revealed that VAC application for intraabdominal sepsis could provide source control, and could reduce the local effects of contamination, control intra-abdominal pressure, and simplify patient care. However, it was also found that VAC offers little promise in the treatment of sepsis. The basic criteria for the termination of VAC therapy and initiation of PAC should aim to prevent peritonitis and regression of intestinal edema, and control contamination. In case of prolonged VAC application, it is believed that peritoneal cytokines will increase, with a negative effect on sepsis. Inflammatory peritoneal fluid findings should be investigated in future studies with a larger cohort of patients. Such an evaluation may validate our findings.

\section{Study Limitations}

Limitations of our study was that the effects of VAC system on mortality could not be completely evaluated as they did not provide standardization for survival, the effects on APACHE IV, MPI, and SOFA scores could be assessed within 12 days.

\section{Conclusion}

The effects on peritonitis macroscopy and expected mortality rate of VAC system used in intraabdominal sepsis were evaluated positively. However, this study defined that the sepsis decreasing effect of VAC was not sufficient. Improvement of peritonitis macroscopy and regression of intraabdominal pressure to normal values were the most important criteria in terminating VAC system and converting to PAC.

Ethics Committee Approval: The study protocol was approved by the Ethics Committee of the Istanbul Bakırköy Dr. Sadi Konuk Training and Research Hospital (decision no: 2019/245).

Informed Consent: Informed consent was obtained from the patients.

Peer-review: Externally peer-reviewed.

Author Contributions: Surgical and Medical Practices - M.Ç., E.G.; Concept - M.Ç.; Design - M.C..; Data Collection and/or Processing - M.Ç. N.A.S.; Analysis and/or Interpretation - M.C.., E.G., N.A.S.; Literature Search - M.Ç.; Writing Manuscript - M.Ç., E.G., N.A.S.

Conflict of Interest: No conflict of interest was declared by the authors.

Financial Disclosure: The authors disclose no financial or other conflicts of interest beyond this pending patent and employee status.

\section{References}

1. Aensio JA, McDuffie L, Petrone P, Roldan G, Forno W, Gambaro E, et al. Reliable variables in the exsanguinated patient which indicate damage control and predict outcome. AJS 2001; 182: 743-51. 
2. Kreis BE, de Mol van Otterloo AJ, Kreis RW. Open abdomen management: a review of its history and a proposed management algorithm. Med Sci Monit 2013; 19: 524-33.

3. Waibel BH, Rotondo MF. Damage control for intra-abdominal sepsis. Surg Clin North Am 2012; 92: 243-57.

4. Hanisch E, Brause R, Paetz J, Arlt B. Review of a large clinical series: Predicting death for patients with abdominal septic shock. J Intensive Care Med 2011; 26: 27-33.

5. Waibel BH, Rotondo MF. Damage control in trauma and abdominal sepsis. Crit Care Med 2010; 38: 421-30.

6. Lamme B, Boermeester MA, Reitsma JB, Mahler CW, Obertop H, Gouma DJ. Met-analysis of relaparotomy for secondary peritonitis. Br J Surg 2002; 89: 1516-24.

7. Mishra SP, Tiwary SK, Mishra M, Gupta SK. An introduction of tertiary peritonitis. J Emerg Trauma Shock 2014; 7: 121-3.

8. Baker SP, O'Neill B, Haddon W Jr, Long WB. The injury severity score: a method for describing patients with multiple injuries and evaluating emergency care. J Trauma 1974; 14: 187-96.

9. Koperna T, Semmler D, Marian F. Risk stratification in emergency surgical patients: is the APACHE II score a reliable marker of physiological impairment? Arch Surg 2001; 36: 55-9.
10. Merrell RC, Latifi R. The abdomen as source of sepsis in critically ill patients. Crit Care Clin 1995; 11: 255-72

11. Jansen J0, Loudon MA. Damage control surgery in a non-trauma setting. $\mathrm{Br}$ J Surg 2007; 94: 789-90

12. Amin AI, Shaikh IA. Topical negative pressure in managing severe peritonitis: a positive contribution? World J Gastroenterol 2009; 15: 3394-7.

13. Schmelzle M, Alldinger I, Matthaei H, Aydin F, Wallert I, Eisenberger CF, et al. Long-term vacuum-assisted closure in open abdomen due to secondary peritonitis: a retrospective evaluation of a selected group of patients. Dig Surg 2010; 27: 272-8

14. Plaudis H, Rudzats A, Melberga L, Kazaka I, Suba O, Pupelis G. Abdomina negative-pressure therapy: a new method in countering abdominal compartment and peritonitis - prospective study and critical review of literature. Ann Intensive Care 2012; 20: 23.

15. Bleszynski MS, Chan T, Buczkowski AK. Comparison of inflammatory cytokines in peritoneal fluid at source control surgery for abdominal sepsis. Am J Surg 2017; 213: 849-55.

16. Sartelli M, Catena F, Di Saverio S, Ansaloni L, Malangoni M, Moore EE, et al. Current concept of abdominal sepsis: WSES position paper. World J Emerg Surg 2014; 9: 22 